\title{
Self Disclosure dan Tingkat Stres pada Mahasiswa yang sedang Mengerjakan Skripsi
}

\author{
Witrin Gamayanti, Mahardianisa, Isop Syafei \\ UIN Sunan Gunung Djati, Jl. A.H. Nasution No. 105 Bandung \\ e-mail: witrin.gamayanti@uinsgd.ac.id
}

\begin{abstract}
Students often experience stress that comes from academic activities. For final-year students, finishing a thesis often become a stressor. Symptoms of stress in students are feeling tired, anxious, not eager to do the thesis. The impact is the thesis is delayed and the students chose to forget it, avoided their lecturers, complained in the social media about the difficulties encountered and ultimately delayed the study period. When experiencing stress, students share their problems to the peer group to get a solution or just to relieve his feelings, called self disclosure. This study aims to determine the influence of self disclosure on stress levels, using method of correlation with simple linear regression analysis. The measuring instrument were the Revised Self Disclosure Scale and the Student-Life Stress Inventory. The participants were 49 students of psychology UIN who are working on thesis. The results showed no influence of self disclosure toward stress levels.
\end{abstract}

Keywords: self disclosure, stress, student

\begin{abstract}
Abstrak
Mahasiswa seringkali mengalami stres yang bersumber dari aktivitas akademiknya. Bagi mahasiswa tingkat akhir, yang sering menjadi stressor adalah menyelesaikan skripsi. Gejala stres pada mahasiswa yaitu merasa lelah, cemas, tidak bersemangat atau ingin berhenti mengerjakan skripsi. Dampaknya adalah pengerjaan skripsi ditunda-tunda dan memilih melupakannya, menghindari dosen pembimbing, mengeluh di media sosial mengenai kesulitan yang dihadapi dan pada akhirnya tertundanya masa studi. Ketika mengalami stres mahasiswa suka berbagi permasalahan kepada orang terdekat untuk mendapatkan solusi atau sekedar untuk melegakan perasaannya, yang disebut dengan self disclosure yang artinya membagi informasi tentang diri sendiri kepada orang lain. Penelitian ini bertujuan untuk mengetahui pengaruh self disclosure terhadap tingkat stres pada mahasiswa. Penelitian menggunakan metode korelasional dengan analisis regresi linier sederhana. Alat ukur menggunakan Revised Self Disclosure Scale dan Student-Life Stress Inventory. Jumlah subjek 49 mahasiswa Fakultas Psikologi UIN SGD Bandung yang sedang mengerjakan skripsi. Hasil penelitian menunjukkan tidak terdapat pengaruh self disclosure terhadap tingkat stres.
\end{abstract}

Kata Kunci: self disclosure, stres, mahasiswa

\section{Pendahuluan}

Stres bisa terjadi pada siapapun termasuk pada mahasiswa. Stres pada mahasiswa bisa disebabkan ketidakmampuan dalam melakukan kewajibannya sebagai mahasiswa atau karena permasalahn lain (Septiani, 2013); tingginya kompleksitas masalah yang dihadapi (Rini, Kartika, \& Qurroyzhin, 2007); kehidupan akademik, terutama dari tuntutan eksternal maupun harapannya sendiri; faktor akademik yang bisa menimbulkan stres bagi mahasiswa yaitu perubahan gaya belajar dari sekolah menengah ke pendidikan tinggi, tugastugas perkuliahan, target pencapaian nilai, prestasi akademik, dan kebutuhan untuk mengatur diri sendiri dan mengembangkan kemampuan berpikir yang lebih baik (Heiman \& Kariv, 2005 dalam Fadillah, 2013); stres pada mahasiswa semester akhir yaitu untuk membuat karya ilmiah atau skripsi (Fadillah, 2013).

Menurut Lazarus dan Folkman (1984), stres berkaitan erat dengan interaksi manusia dan lingkungan, karenanya stres 
bisa dipahami sebagai hubungan atau interaksi antara individu dengan lingkungan yang dihayati sebagai beban atau dirasakan melebihi kekuatannya.

Menurut Handoyo (2001 dalam Fadillah, 2013), stres bisa berupa tuntutan dari eksternal yang dihadapi seseorang yang kenyataannya memang membahayakan atau menimbulkan permasalahan. Stres juga bisa dipahami sebagai tekanan, ketegangan atau gangguan yang bersumber dari eksternal dan dirasakan tidak menyenangkan.

Pendapat lain disampaikan oleh Abdulghani (2008) yang mengatakan bahwa stres itu bisa berdampak positif atau negatif. Stres bisa berdampak positif ketika tekanan itu tidak melebihi toleransi stresnya atau tidak melebihi kemampuan dan kapasitas dirinya. Dampak positif stres terhadap mahasiswa diantaranya tertantang untuk mengembangkan diri dan menumbuhkan kreativitas. Dampak negatif dari stres bisa berupa sulit memusatkan perhatian (konsentrasi) selama perkuliahan termasuk saat mengikuti proses bimbingan skripsi dengan dosen pembimbingnya, menurunnya minat terhadap hal-hal yang biasa ia kerjakan, menurunnya motivasi bahkan memengaruhi perilaku menjadi kurang adaptif.

Stressor yang dirasakan melebihi kapasitas dan kemampuan seseorang bisa menjadi ancaman, misalnya kesulitan menyelesaikan skripsi sehingga merasa tidak sanggup untuk menuntaskan, yang membuat skripsi tidak kunjung selesai dan membuat masa studi menjadi lama.

Gejala stres yang muncul umumnya dibagi ke dalam tiga aspek, pertama gejala fisik berupa gangguan tidur (tidak bisa tidur atau terbangun tengah malam dan tidak bisa melanjutkan tidurnya) dan berubahnya selera makan. Gejala emosional berupa perubahan suasana hati, merasa gelisah, cemas dan tidak memiliki semangat dalam melakukan akivitas (malas). Gejala berupa tidak bisa fokus dalam berpikir, pikiran menjadi kacau dan berpikir negatif menjadi meningkat (Astiko, 2013 dalam Putri \& Savari, 2013); dan pikiran menjadi kacau (Rini, Kartika, \& Qurroyzhin, 2007).

Fenomena yang peneliti amati, stres pada mahasiswa karena menyusun skripsi terjadi pada mahasiswa Fakultas Psikologi UIN SGD Bandung angkatan 2012 yaitu berkeluh kesah, sering merasa lelah, pusing, terlihat cemas dan tidak bersemangat, bahkan ada beberapa yang merasa ingin mengakhiri studinya begitu saja atau membuat status di media sosial berisi keluhan tentang perasaannya ketika mengalami kendala dalam menyelesaikan skripsi. Dampak stres lainnya adalah sengaja tidak mengerjakan skripsi karena tidak ingin merasa terbebani sehingga lebih memilih mencari kesenangan dari kegiatan lain di luar kampus dan menghindari dosen pembimbing. Hal ini membuat banyaknya mahasiswa angkatan 2012 yang menjadi subjek penelitian tidak dapat menyelesaikan studinya dengan tepat waktu.

Melihat dampak stres yang tidak ringan, perlu teknik yang tepat untuk mengurangi atau menghilangkan dampak stres. Lazarus dan Folkman (1984) mengatakan bahwa salah satu cara untuk memahami pertanyaan-pertanyaan mengenai stres adalah dengan mengetahui lebih lanjut tentang situasi yang dialami. Salah satu upaya untuk mengetahui situasi tersebut adalah dengan membuka diri. Keterbukaan diri atau self disclosure yang baik kemungkinan dapat meringankan stres. Peneliti mengamati hal ini dilakukan oleh sebagian mahasiswa, ketika mereka bertemu sebelum bimbingan atau sekedar duduk di selasar kampus, mereka saling berbagi permasalahan mengenai proses penyelesaian skripsi. Hal itu bisa mengurangi beban karena merasa ada teman senasib atau bisa katarsis, mengeluarkan semua perasaannya.

Manusia merupakan makhluk sosial yang dalam hidupnya selalu memerlukan dan membutuhkan orang lain, termasuk saat seseorang mengalami tekanan yang 
bisa menimbulkan stres. Self disclosure yaitu keterbukaan diri atau pengungkapan diri. Menurut DeVito (2011) self disclosure adalah jenis komunikasi yaitu seseorang terbuka mengungkapkan informasi mengenai dirinya (pikiran, perasaan, dan perilaku). Self disclosure adalah ketika seseorang mengungkapkan informasi pribadi mengenai dirinya kepada orang lain, salah satu manfaatnya adalah untuk mendapatkan bantuan dan dukungan atau mencapai kontrol sosial (Rime, 2016).

Efek dari self disclosure adalah mengurangi stres (Derlega dkk., 1993; Kahn \& Hessling, 2001; Stiles, 1987, dalam Zhang, 2017); dikaitkan dengan dua mekanisme, pertama, melampiaskan perasaan negatif dapat membangkitkan perasaan lega. Efek dari perasaan negatif tersebut menjadi berkurang bila diekspresikan atau diceritakan kepada orang lain, hal tersebut disebut "katarsis" (Stiles, 1987 dalam Zhang, 2017). Kedua, self disclosure bisa membuat pikiran menjadi tenang dan tidak terganggu oleh kejadian yang muncul, sehingga memungkinkan individu mengevaluasi dan memahami masalah yang sedang atau telah dialami dan meningkatkan kemampuan yang ada pada diri individu (Feldman, Joorman, \& Johnson, 2008 dalam Zhang, 2017); mendapatkan keuntungan sosial (Derlega dkk., 1993 dalam Zhang, 2017); dengan self-disclosure seseorang mendapatkan sumber daya dari orang lain, baik itu dukungan emosional atau bantuan nyata (Clark \& Mills, 1979 dalam Zhang, 2017); menumbuhkan hubungan yang interdependensi, saling memberi yang bisa memunculkan rasa aman, self-acceptance, bisa memahami diri sendiri dan memperoleh solusi dari permasalahan yang sedang dihadapi.

Dalam mengungkapkan diri, individu juga dapat menceritakan permasalahanpermasalahan atau stres yang ia alami dan bisa mendapatkan tanggapan, informasi, saran, ataupun dukungan dari orang lain. Timbal balik tersebut dapat memberikan individu persepsi lain terhadap apa yang ia alami (Asandi, 2010).

Dampak lain dari self disclosure adalah individu yang sengaja berbagi pengalaman dan emosi dapat membantu mengurangi gejala depresi pada saat stres dan akan mengalami peningkatan kepuasan hidup ketika self disclosure dilakukan dengan penuh kedekatan (Zhang, 2017); bisa terbuka mengatakan masalah pribadi secara tepat, lebih adaptif dalam menyesuaikan diri, memiliki kepercayaan diri yang lebih baik, kompeten, bisa diandalkan, bersikap positif, mempercayai orang lain, objektif dan lebih terbuka (Johnson, 1981 dalam Gainau, 2009).

Individu yang kurang mampu membangun keterbukaan dengan orang lain tumbuh menjadi orang yang keterampilan sosialnya terganggu, kepercayaan diri rendah, yang menimbulkan perasaan takut, cemas, self esteem rendah dan tertutup. Itu semua memengaruhi kesehatan mental seseorang (Johnson, 1981 dalam Gainau, 2009).

Penelitian lain yang dilakukan terhadap sejumlah mahasiswa psikologi yang sedang menyusun skripsi di UNDIP membuktikan bahwa terdapat hubungan antara efektivitas komunikasi mahasiswa-dosen pembimbing utama skripsi dengan stres dalam menyusun skripsi (Gunawati, 2006). Semakin efektif komunikasi antara mahasiswa dan dosen pembimbing utama maka semakin rendah tingkat stresnya. Penelitan tersebut berkaitan dengan yang akan peneliti teliti yaitu self disclosure atau keterbukaan diri yang merupakan salah satu aspek dari efektivitas komunikasi interpersonal menurut DeVito (2011).

Untuk mahasiswa psikologi self disclosure merupakan hal yang penting, berkaitan dengan perannya di kemudian hari sebagai seorang psikolog. Pertama, self disclosure membantu melatih kemampuan untuk berbagi ketika mendapatkan tekanan dan bisa menjadi katarsis, melatih meregulasi perasaan, mengenal masalah secara objektif dan potensi pribadinya 
dalam menuntaskan persoalan dan mengetahui waktu yang tepat untuk meminta masukan dari orang-orang di sekitarnya. Kedua, ketika berhadapan dengan kliennya, keterbukaan dengan penuh kesadaran dalam batas-batas tertentu membantu meningkatkan efektivitas konseling. Keterbukaan psikolog dalam konseling atau sesi terapi dapat mendorong klien untuk membuka dirinya.

Berdasarkan penjelasan sebelumya, peneliti ingin mengetahui apakah ada pengaruh self disclosure terhadap tingkat stres mahasiswa yang sedang menyelesaikan skripsi.

\section{Self Disclosure}

Komponen yang paling penting dalam berkomunikasi adalah diri (self). Self adalah "kelengkapan psikologis yang memungkinkan refleksi diri berpengaruh terhadap pengalaman kesadaran, yang mendasari semua jenis persepsi, kepercayaan dan perasaan tentang diri sendiri serta yang memungkinkan seseorang meregulasi tentang perilakunya sendiri" (Leary, McDonald, \& Tangney, 2003 dalam Rahman, 2013)

Pengungkapan diri menurut Jourard (dalam Gainau, 2009) berarti pembicaraan mengenai diri sendiri kepada orang lain sehingga orang lain mengetahui apa yang dipikirkan, dirasakan dan diinginkan oleh seseorang.

DeVito (2011) mengemukakan bahwa pengungkapan diri merupakan jenis komunikasi dimana kita mengungkapkan informasi diri pribadi yang biasanya kita sembunyikan kepada orang lain. Pengungkapan diri dapat berupa berbagai topik seperti informasi perilaku, sikap, perasaan, keinginan, motivasi, dan ide yang sesuai dan terdapat dalam diri orang yang bersangkutan.

Menurut Wheeless, Nesser, dan Mccroskey (1986), self disclosure adalah bagian dari referensi diri yang dikomunikasikan yang diberikan individu secara lisan pada suatu kelompok kecil.
Sedangkan Person (dalam Gainau, 2009) mengartikan self disclosure sebagai tindakan seseorang dalam memberikan informasi yang bersifat pribadi pada orang lain secara sukarela dan disengaja untuk maksud memberi informasi akurat tentang dirinya.

Jadi dapat disimpulkan bahwa self disclosure adalah bentuk komunikasi yang membiarkan orang lain tahu tentang pemikiran, keinginan, dan perasaan diri sendiri yang sebenarnya.

Menurut Wheeles (1986 dalam Devito, 2011) dimensi dalam self disclosure dibagi menjadi lima bagian yaitu: Pertama, Ukuran atau jumlah self disclosure. Ukuran self disclosure didapat dari frekuensi dan durasi pesan-pesan yang bersifat self disclosure atau waktu yang diperlukan untuk menyatakan pengungkapan tersebut. Kedua, Valensi. Valensi merupakan hal yang positif atau negatif dari pengungkapan diri. Individu dapat mengungkapkan diri mengenai hal-hal yang menyenangkan atau tidak menyenangkan mengenai dirinya, memuji hal-hal yang ada dalam dirinya atau menjelek-jelekkan diri individu sendiri. Faktor nilai juga memengaruhi sifat dasar dan tingkat pengungkapan diri. Ketiga, Ketepatan dan Kejujuran. Ketepatan dari pengungkapan diri individu dibatasi oleh tingkat di mana individu mengetahui dirinya sendiri. Pengungkapan diri berbeda dalam hal kejujuran, individu bisa saja jujur secara total atau dilebih-lebihkan, melewatkan bagian penting atau berbohong. Keempat, Tujuan dan Maksud. Seluas apa individu mengungkapkan tentang apa yang ingin diungkapkan, seberapa besar kesadaran individu untuk mengontrol informasi-informasi yang akan dikatakan pada orang lain. Kelima, Kedalaman. Individu dapat mengungkapkan detail yang paling intim dari hidupnya. Hubungan yang akrab adalah individu yang mampu mengungkapkan hal-hal yang bersifat pribadi dan khusus tentang dirinya. Sejauh mana kedalaman dalam self disclosure itu 
akan ditentukan oleh derajat keakraban individu dengan lawan komunikasinya (Buwana, 2015).

Menurut Derlega dan Grzelak (dalam Pamuncak, 2011) ada lima alasan untuk melakukan self disclosure: Pertama, Expression. Dalam kehidupan ini terkadang manusia mengalami suatu kekecewaan atau kekesalan, baik itu yang menyangkut pekerjaan ataupun yang lainnya. Untuk membuang semua kekesalan ini biasanya akan merasa senang bila bercerita pada seorang teman yag sudah dipercaya. Dengan pengungkapan diri semacam ini manusia mendapat kesempatan untuk mengekspresikan perasaannya. Kedua, Self Clarification. Dengan saling berbagi rasa serta menceritakan perasaan dan masalah yang sedang dihadapi kepada orang lain, manusia berharap agar dapat memperoleh penjelasan dan pemahaman orang lain akan masalah yang dihadapi sehingga pikiran akan menjadi lebih jernih dan dapat melihat persoalannya dengan baik. Ketiga, Social Validation. Setelah selesai membicarakan masalah yang dihadapi, biasanya pendengar akan memberikan tanggapan mengenai permasalahan tersebut. Sehingga dengan demikian, akan mendapatkan suatu informasi yang bermanfaat. Individu mendapat informasi tentang kebenaran dan ketepatan pandangannya. Keempat, Social Control. Individu mungkin mengungkapkan atau menyembunyikan informasi tentang dirinya, sama seperti arti dari kontrol sosial. Individu mungkin menekan topik, kepercayaan atau ide yang akan membentuk pesan atau kesan baik tentang dirinya. Kelima, Relationship Development. Saling berbagi rasa dan informasi tentang diri kita kepada orang lain serta saling mempercayai merupakan saran yang paling penting dalam usaha merintis suatu hubungan sehingga akan semakin meningkat derajat keakraban.

Menurut DeVito (2011) manfaat dari melakukan self disclosure adalah: (1). Pengetahuan diri. Salah satu manfaat dari pengungkapan diri adalah kita mendapatkan perspektif baru tentang diri kita sendiri serta pemahaman yang lebih mendalam mengenai perilaku kita sendiri; (2). Kemampuan mengatasi kesulitan. Argumen lain yang berkaitan erat adalah bahwa kita akan lebih mampu menanggulangi masalah atau kesulitan kita, khususnya perasaan bersalah, melalui pengungkapan diri. Dengan mengungkapkan perasaan dan menerima dukungan, bukan penolakan, kita menjadi lebih siap untuk mengatasi perasaan bersalah dan mungkin mengurangi atau bahkan menghilangkannya. Bahkan penerimaan diri (self acceptance) menjadi sulit tanpa pengungkapan diri. Kita menerima diri kita sebagian besar melalui kacamata orang lain. Jika kita merasa orang lain menolak kita, kita cenderung menolak diri sendiri juga. Melalui pengungkapan diri dan dukungan-dukungan yang datang, kita menempatkan diri sendiri dalam posisi yang lebih baik untuk menangkap tanggapan positif kepada kita dan kita akan lebih mungkin memberikan reaksi dengan mengembangkan konsep diri yang positif; (3). Efisiensi komunikasi. Pengungkapan diri memperbaiki komunikasi. Kita memahami pesan-pesan dari orang lain sebagian besar sejauh kita memahami orang lain secara individual. Kita dapat lebih memahami apa yang dikatakan seseorang jika kita mengenal baik orang tersebut. Pengungkapan diri adalah kondisi yang penting untuk mengenal orang lain. Kita dapat saja meneliti perilaku seseorang atau bahkan hidup bersamanya selama bertahun-tahun, tetapi jika orang itu tidak pernah mengungkapkan dirinya, kita tidak akan memahami orang itu sebagai pribadi yang utuh; (4). Kedalaman hubungan. Tanpa pengungkapan diri, hubungan yang bermakna dan mendalam tidak mungkin terjadi. Dengan pengungkapan diri, kita memberi tahu orang lain bahwa kita mempercayai mereka, menghargai mereka, dan cukup peduli akan mereka maupun hubungan kita untuk mengungkapkan diri kita kepada mereka. Hal tersebut kemudian 
akan membuat orang lain mau membuka diri dan membentuk suatu hubungan yang bermakna dan jujur.

\section{Stres}

Folkman dan Lazzarus (1984) mendefinisikan stres sebagai suatu akibat dari interaksi antara seseorang dengan lingkungannya yang dinilai membahayakan dirinya. Selye (dalam Santrock, 2006) stres adalah kerusakan yang dialami tubuh akibat berbagai tuntutan yang dialamatkan padanya.

Sarafino (2008) mengemukakan stres sebagai kondisi akibat dari interaksi individu dengan lingkungan yang menimbulkan ketidaksesuaian antara tuntutantuntutan yang bersumber pada sistem biologis, psikologis, dan sosial individu. Sedangkan Taylor (1997 dalam Suryaningsih dkk., n.d) stres merupakan suatu pengalaman emosional negatif yang disertai dengan perubahan biokimia, fisiologi, kognitif, dan perilaku yang dapat diarahkan untuk mengurangi atau menyesuaikan diri terhadap peristiwa yang memicu stres dengan cara mengubah kejadian ataupun mengakomodasikan efek dari stres tersebut.

Ahli lain, Kendal dan Hammen (1998 dalam Safaria \& Saputra, 2009) menyatakan stres dapat terjadi pada individu ketika terdapat ketidakseimbangan antara situasi yang menuntut dengan perasaan individu atas kemampuannya untuk menghadapi tuntutan-tuntutan tersebut. Situasi yang menuntut tersebut dipandang sebagai beban atau melebihi kemampuan individu untuk mengatasinya.

Berdasarkan berbagai pengertian dari para ahli dapat disimpulkan bahwa stres merupakan suatu keadaan yang menekan seseorang yang dirasakan melebihi kemampuan yang dimilikinya. Stres dapat menghasilkan respon yang saling terkait baik fisiologis, psikologis, maupun perilaku pada individu yang mengalaminya.

Menurut Helmi (2000 dalam Safaria \& Saputra, 2009) ada empat macam reaksi stres, yaitu reaksi psikologis, fisiologis, proses berpikir, dan tingkah laku. Berbagai penelitian telah membuktikan bahwa respon-respon tersebut dapat berguna sebagai indikator terjadinya stres pada individu, dan mengukur tingkat stres yang dialami individu. Reaksi stres terlihat dalam berbagai aspek, yaitu: (1). Reaksi psikologis, biasanya lebih dikaitkan pada aspek emosi, seperti mudah marah, sedih, ataupun mudah tersinggung; (2). Reaksi fisiologis, biasanya muncul dalam keluhan fisik, seperti pusing, nyeri tengkuk, tekanan darah naik, nyeri lambung, gatal-gatal di kulit, ataupun rambut rontok; (3) Reaksi kognitif, biasanya tampak dalam gejala sulit berkonsentrasi, mudah lupa, ataupun sulit mengambil keputusan; (4). Reaksi tingkah laku, tampak dari perilaku-perilaku menyimpang, misalnya menyakiti diri sendiri atau orang lain atau menghindar dari temannya.

Menurut Lahey (2003 dalam Septiani, 2013) ada beberapa sumber utama stres: (1). Life event (perstiwa dalam hidup) yaitu kejadian penting secara psikologis yang terjadi pada kehidupan seseorang, seperti perceraian, kelahiran, atau perubahan pada posisi/ jabatan. Umumnya penyebab stres itu dapat berupa tindak kriminal, kekerasan seksual, dan saksi kejahatan; kehilangan anggota keluarga; bencana alam; teror; masalah-masalah sehari-hari (daily hasles). (2). Frustration (frustrasi), merupakan keadaan yang muncul sebagai hasil tidak terpuaskannya suatu tujuan atau motif seseorang. (3). Conflict (konflik), merupakan keadaan dimana terdapat dua atau lebih motif yang tidak terpuaskan karena motifmotif itu saling berkaitan satu sama lain. (4) Pressure (tekanan), merupakan suatu keadaan yang menimbulkan konflik, dimana individu merasa terpaksa atau dipaksa untuk tidak melakukan hal-hal yang diinginkannya. Tekanan yang kecil, tetapi bila bertumpuk-tumpuk dapat menjadi stres yang hebat. Tekanan dapat berasal dari luar diri maupun dari dalam diri sendiri. 
Para peneliti membedakan antara stres yang merugikan atau merusak yang disebut sebagai distress dan stres yang menguntungkan atau membangun, yang disebut sebagai eustress (Safaria \& Saputra, 2009). Selye (1979 dalam Wulandari, 2012) membagi stres menjadi dua, yaitu eustress dan distress.

Stress. Stres yang menghasilkan respon individu bersifat sehat, positif, dan membangun. Respon positif tersebut tidak hanya dirasakan oleh individu tetapi juga oleh lingkungan sekitar individu, seperti dengan adanya pertumbuhan, fleksibilitas, kemampuan adaptasi, dan tingkat performance yang tinggi. Eustress juga merupakan situasi atau kondisi apapun yang dapat memberikan inspirasi dan memberikan motivasi untuk bertindak positif. Biasanya situasi yang termasuk dalam situasi yang membangkitkan semangat individu untuk bertingkah laku secara positif dan mengoptimalkan seluruh fungsi fisik dan psikisnya. Situasi ini dimasukkan ke dalam stres, karena menimbulkan reaksi fisik dan psikologis yang sama, dengan peningkatan hormon dari kelenjar adrenalin dan adanya gejolak emosi. Dapat dikatakan bahwa stres yang baik berasal dari situasi yang dapat dikendalikan (Roshental, 2003 dalam Septiani 2013).

Distress. Distress adalah stres yang berlawanan dengan eustress, yaitu tidak sehat, negatif, dan merusak. Hal tersebut termasuk konsekuensi individu dan juga organisasi seperti tingkat ketidakhadiran yang tinggi, sulit berkonsentrasi, sulit menerima hasil yang didapat. Stres buruk ini banyak dibahas oleh para ahli karena dampaknya yang begitu besar terhadap kehidupan individu. Distress atau stres negatif ini dapat dibagi menjadi dua macam yaitu: Pertama, stres akut, muncul cukup kuat, tapi menghilang dengan cepat. Misalnya ketika mendapat tekanan atau ancaman dari orang lain, atau ketika terlambat ke tempat kuliah dan lain-lain. Kedua, stres kronis kemunculannya tidak terlalu kuat, tapi bisa bertahan lama sampai berhari-hari, berminggu-minggu, atau berbulan-bulan. Stres ini apabila berulangulang terjadi pada diri kita maka kesehatan tubuh dan produktivitas akan terpengaruh. Inti dari stres ini yaitu dapat menyebabkan kesakitan baik itu secara mental, spiritual, dan lain sebagainya (Roshental, 2002 dalam Septiani, 2013).

Rice (dalam Septiani, 2013) mengatakan bahwa penyebab stres atau yang sering disebut stressor dapat berasal dari dalam diri individu (internal) dan dapat pula berasal dari luar diri individu (eksternal).

Stressor internal. Faktor-faktor yang berasal dari dalam diri individu yang dapat menjadi penyebab timbulnya stres. Penyebab stres yang berasal dari dalam diri individu, misalnya harga diri dan konsep diri. Sesuatu yang menimbulkan stres tergantung bagaimana individu menilai dan menginterpretasikan suatu kejadian secara kognitif. Penilaian secara kognitif adalah istilah untuk menggambarkan interpretasi individu terhadap kejadian-kejadian dalam hidup mereka sebagai sesuatu yang berbahaya, mengancam, dan keyakinan mereka dalam menghadapi kejadian tersebut secara efektif.

Stressor eksternal. Faktor-faktor luar yang dapat menyebabkan individu mengalami stres. Selanjutnya, menurut Maramis (2008 dalam Larasaty, 2012) lingkungan merupakan salah satu sumber stres pada individu. Sebagai contoh seorang mahasiswa dihadapkan pada beban tuntutan dari lingkungan. Selain itu, mahasiswa seringkali memiliki konflik permasalahan dengan teman sebaya. Berbagai macam permasalahan pada akhirnya dapat memicu timbulnya stres. Morgan (dalam Septiani, 2013) mengemukakan bahwa perubahan dalam lingkungan, seperti kelahiran anak, kematian pasangan, pernikahan yang tidak bahagia, perceraian, hubungan interpersonal dengan orang-orang yang ada di sekitar dapat menimbulkan stres. 
Berdasarkan hal itu hipotesis penelitiannya adalah terdapat pengaruh antara self-disclosure dengan tingkat stres pada mahasiswa fakultas psikologi UIN SGD Bandung angkatan 2012 yang sedang menyelesaikan skripsi.

\section{Metode Penelitian}

$\begin{array}{ccc}\begin{array}{c}\text { Penelitian } \\ \text { pendekatan }\end{array} & \text { ini } & \begin{array}{c}\text { menggunakan } \\ \text { kuantiatif }\end{array} \\ \text { korelasional. }\end{array}$ Populasi dalam penelitian ini adalah mahasiswa aktif di Fakultas Psikologi UIN Bandung angkatan 2012 dengan jumlah sampel 49 mahasiswa.

Metode pengumpulan data. Instrumen menggunakan model skala Likert. Alat ukur self-disclosure yaitu Revised Self Disclosure Scale dari Wheeles yang diadaptasi dari Ables (2013) dan tingkat stres yaitu Student-Life Stress Inventory yang dikembangkan oleh Gadzella (1991 dalam Goff, 2009).

Metode Analisis Data. Data yang diperoleh dianalisis dengan menggunakan analisis regresi linier sederhana. Dalam penelitian ini dilakukan juga uji validitas konstruk, dengan menggunakan formula pearson. Sedangkan prinsip umum dalam menginterpretasikan koefisien validitas, menggunakan klasifikasi Guillford (Sugiyono, 2012) yang disajikan pada tabel 1.

Tabel 1

Klasifikasi Koefisien Korelasi Guillford

\begin{tabular}{ll}
\hline Koefisien Korelasi & \multicolumn{1}{c}{ Keterangan } \\
\hline $0.00-0.19$ & Korelasi dangat rendah \\
$0.20-0.39$ & Korelasi rendah \\
$0.40-0.59$ & Korelasi sedang \\
$0.60-0.79$ & Korelasi tinggi \\
$0.80-0.99$ & Korelasi tinggi sekali \\
1.00 & Korelasi sempurna \\
\hline
\end{tabular}

Berdasarkan hasil perhitungan, maka didapat nilai validitas tiap aspek untuk skala self-disclosure dan tingkat stres yang sudah dibandingkan dengan tabel klasifikasi koefisien korelasi Guillford, diperoleh hasil sebagaimana disajikan pada tabel 2.
Tabel 2

Validitas Skala Self Disclosure

\begin{tabular}{lcc}
\hline Aspek & Koefisien Korelasi & Keterangan \\
\hline Intent & 0.62 & Tinggi \\
Amount & 0.86 & Tinggi Sekali \\
Valensi & 0.80 & Tinggi Sekali \\
Depth & 0.78 & Tinggi \\
Honesty & 0.65 & Tinggi \\
\hline
\end{tabular}

Selanjutnya dari hasil perhitungan Cronbach's Alpha didapat koefisien reliabilitas skala self-disclosure sebesar 0.89, Hasil koefisien reliabilitas skala tingkat stres sebesar 0.89. Nilai tersebut mempunyai arti bahwa skala self-disclosure dan skala tingkat stres mempunyai tingkat reliabilitas yang sangat tinggi.

\section{Hasil Penelitian dan Pembahasan}

\section{Hasil Penelitian}

\section{Analisis deskriptif.}

Analisis deskriptif self disclosure. Berdasarkan penelitian yang dilakukan terhadap variabel self-disclosure maka didapat data sebagai berikut:

Berdasarkan hasil perhitungan terhadap variabel self-disclosure diperoleh mean sebesar 53.69, serta nilai standart deviation (SD) sebesar 6.37. Nilai minimum dan maksimum menunjukkan bahwa nilai paling kecil dalam penelitian ini (self-disclosure) adalah 41.00 dan nilai paling besar adalah 76.00.

Subjek penelitian digolongkan menjadi tiga kategori yaitu: tinggi, sedang, rendah. Langkah yang dilakukan adalah membagi skor maksimum hipotetik menjadi tiga. Dengan rumus sebagai berikut:

$$
\begin{array}{ll}
\mathrm{X}<\mathrm{M}-1 . \mathrm{SD} & =\text { Rendah } \\
\mathrm{M}-1 . \mathrm{SD}=\mathrm{X}<\mathrm{M}+1 . \mathrm{SD} & =\text { Sedang } \\
\mathrm{M}+1 . \mathrm{SD}=\mathrm{X} & =\text { Tinggi }
\end{array}
$$

Dengan demikian variabel selfdisclosure memiliki rentang 60.06 untuk kategori tinggi, $\geq 47.28$ untuk kategori sedang, dan $\geq 47.28$ untuk kategori rendah. Berdasarkan kategorisasi memperlihatkan bahwa self-disclosure $12.24 \%$ tinggi, $71.43 \%$ sedang, dan $16.33 \%$ rendah. Hasil 
tersebut memperlihatkan bahwa tingkat self-disclosure pada subjek penelitian paling banyak berada pada kategori sedang. Dapat dilihat pada tabel 3.

Tabel 3

Kategori Skor Variabel Self-Disclosure

\begin{tabular}{lccc}
\hline Kategori & Skor & Jumlah & Persentase \\
\hline Tinggi & $60.06=\mathrm{X}$ & 6 & $12.24 \%$ \\
Sedang & $\begin{array}{c}47.28=\mathrm{X} \\
<60.06\end{array}$ & 35 & $71.43 \%$ \\
& & \\
Rendah & $\mathrm{X}<47.28$ & 8 & $16.33 \%$ \\
\hline
\end{tabular}

Analisis deskriptif tingkat stres. Berdasarkan penelitian yang dilakukan terhadap variabel tingkat stres maka didapat data sebagai berikut:

Berdasarkan hasil perhitungan terhadap variabel tingkat stres diperoleh nilai mean sebesar 52.30 serta nilai standart deviation (SD) sebesar 8.54. Nilai minimum dan maksimum menunjukkan bahwa nilai paling kecil dalam penelitian ini (tingkat stres) adalah 36.00 dan nilai paling besar adalah 70.00 .

Subjek penelitian kemudian digolongkan menjadi tiga kategori yaitu: tinggi, sedang, rendah. Langkah yang dilakukan adalah membagi skor maksimum hipotetik menjadi tiga. Dengan rumus sebagai berikut:

$$
\begin{array}{ll}
\mathrm{X}<\mathrm{M}-1 . \mathrm{SD} & =\text { Rendah } \\
\mathrm{M}-1 . \mathrm{SD}=\mathrm{X}<\mathrm{M}+1 . \mathrm{SD} & =\text { Sedang } \\
\mathrm{M}+1 . \mathrm{SD}=\mathrm{X} & =\text { Tinggi }
\end{array}
$$

Dengan demikian variabel tingkat stres memiliki rentang 60.85 untuk kategori tinggi, $\geq 43.75$ untuk kategori sedang, dan $\geq 43.75$ untuk kategori rendah. Berdasarkan kategorisasi memperlihatkan bahwa tingkat stres 6 subjek tinggi, 34 subjek sedang, dan 9 subjek rendah. Hasil tersebut memperlihatkan bahwa secara umum tingkat stres pada subjek penelitian paling banyak berada pada kategori sedang. Dapat dilihat pada tabel 4 .

Tabel 4

Kategori Skor Variabel Tingkat Stres

\begin{tabular}{lccc}
\hline Kategori & Skor & Jumlah & Persentase \\
\hline Tinggi & $60.85=\mathrm{X}$ & 6 & $12.24 \%$ \\
\hline
\end{tabular}

\begin{tabular}{cccc}
\hline Sedang & $\begin{array}{c}43.75=\mathrm{X} \\
<60,85\end{array}$ & 34 & $69.39 \%$ \\
\hline Rendah & $\mathrm{X}<43.75$ & 9 & $18.37 \%$ \\
\hline
\end{tabular}

Berdasarkan hasil perhitungan tabulasi silang menunjukkan bahwa subjek pada penelitian ini dominan memiliki selfdisclosure pada kategori sedang dengan tingkat stres pada kategori sedang pula yang berjumlah 25 subjek atau $51 \%$.

Tabel 5

Distribusi Silang Self-Disclosure dengan Tingkat Stress

\begin{tabular}{lllrrrr}
\hline & & \multicolumn{3}{c}{ Self Disclosure } & \\
\cline { 3 - 5 } & & & Rendah & Sedang & Tinggi & Total \\
\hline \multirow{3}{*}{$\begin{array}{l}\text { Tingkat } \\
\text { Stres }\end{array}$} & Rendah & Count & 3 & 5 & 1 & 9 \\
\cline { 2 - 6 } & & $\%$ of Total & $6,1 \%$ & $10,2 \%$ & $2,0 \%$ & $18,4 \%$ \\
\cline { 2 - 6 } & Sedang & Count & 5 & 25 & 4 & 34 \\
\cline { 2 - 6 } & & $\%$ of Total & $10,2 \%$ & $51,0 \%$ & $8,2 \%$ & $69,4 \%$ \\
\cline { 2 - 6 } & Tinggi & Count & 0 & 5 & 1 & 6 \\
\cline { 2 - 6 } & & \% of Total & $0,0 \%$ & $10,2 \%$ & $2,0 \%$ & $12,2 \%$ \\
\hline Total & Count & 8 & 35 & 6 & 49 \\
\cline { 2 - 6 } & & \% of Total & $16,3 \%$ & $71,4 \%$ & $12,2 \%$ & 100,0 \\
& & & & & \\
\hline
\end{tabular}

Analisis inferensial. Dalam analisis inferensial yang pertama dijelaskan adalah nilai korelasi dan determinasi berdasarkan tabel 6.

Table 6

Koefisien Determinasi

\begin{tabular}{lcrrr}
\hline Model & $\mathrm{R}$ & $\begin{array}{c}\mathrm{R} \\
\text { Square }\end{array}$ & $\begin{array}{c}\text { Adjusted } \\
\text { R Square }\end{array}$ & $\begin{array}{c}\text { Std. Error of the } \\
\text { Estimate }\end{array}$ \\
\hline 1 & $094^{\mathrm{a}}$ & 0,009 & $-0,012$ & 8,60153 \\
\hline
\end{tabular}

Nilai korelasi sebesar 0.094 menunjukkan adanya korelasi antara selfdisclosure dengan tingkat stres dengan nilai determinasi 0.009. Angka tersebut berarti bahwa $0.9 \%$ terdapat pengaruh selfdisclosure terhadap tingkat stres, sedangkan sisanya $99.1 \%$ harus dijelaskan oleh faktor-faktor penyebab lainnya.

\begin{tabular}{|c|c|c|c|c|c|c|}
\hline Mode & & $\begin{array}{l}\text { Sum of } \\
\text { Squares }\end{array}$ & $\mathrm{df}$ & $\begin{array}{l}\text { Mean } \\
\text { Square }\end{array}$ & F & Sig. \\
\hline \multirow[t]{3}{*}{1} & Regression & 31,049 & 1 & 31,049 & 0,420 & $.520^{\mathrm{b}}$ \\
\hline & Residual & 3477,359 & 47 & 73,986 & & \\
\hline & Total & 3508,408 & 48 & & & \\
\hline
\end{tabular}

Tabel 7

Perhitungan ANOVA 
Kedua, dari hasil perhitungan diperoleh data bahwa pengaruhnya tidak linier karena nilai signifikansinya > dari 0.05 . Nilai sig $0.520>0.05$.

Tabel 8

Hasil Koefisien Regresi

\begin{tabular}{lcccccc}
\hline & & \multicolumn{2}{c}{$\begin{array}{c}\text { Unstandardized } \\
\text { Coefficients }\end{array}$} & $\begin{array}{c}\text { Standardized } \\
\text { Coefficients }\end{array}$ & & \\
\cline { 2 - 4 } Model & $\mathrm{B}$ & $\begin{array}{c}\text { Std. } \\
\text { Error }\end{array}$ & Beta & & Sig. \\
\hline $1 \quad$ & (Constant) & 45.545 & 10,508 & & 4,334 & 0,000 \\
& & & & & \\
& $\begin{array}{l}\text { Self } \\
\text { Disclosure }\end{array}$ & $0 ., 126$ & 0,194 & 0,094 & 0,648 & 0,520 \\
& & & & & \\
\hline
\end{tabular}

a. Dependent Variable: Tingkat Stres

Ketiga, diperoleh data bahwa pengaruh self-disclosure terhadap tingkat stres tidak signifikan, dengan nilai $\mathrm{t}=0.648$ dan nilai sig. 0.52>0.05. Karena tingkat signifikansi $0.520>0.05$, maka variabel self-disclosure dikatakan tidak dapat memprediksikan tingkat stres.

Pada tabel 8 dapat dilihat pada bagian kolom Beta menunjukkan bahwa terdapat korelasi positif sebesar 0.094 antara selfdisclosure dengan tingkat stres pada mahasiswa psikologi UIN SGD Bandung angkatan 2012. Selanjutnya untuk melihat persamaan regresinya adalah sebagai berikut:

$\hat{\mathrm{Y}}=a+b X$

Dengan:

Ý : Nilai dari variabel terikat (dependent)

$\mathrm{X}$ : Nilai dari variabel bebas (independent)

a : Nilai konstanta, yaitu 45.545

b : Koefisien regresi, yaitu 0.126

Nilai-nilai pada tabel 8 kemudian dimasukkan ke dalam persamaan regresi sebagai berikut:

$\hat{Y}=45.54+0.126 X$
Nilai 45.54 merupakan nilai konstanta. Artinya jika variabel self-disclosure nilainya 0 maka variabel tingkat stres memiliki nilai positif sebesar 45.54.

\section{Pembahasan}

Sesuai dengan tujuan yang sudah dijelaskan di awal, penelitian ini bertujuan untuk melihat adanya pengaruh selfdisclosure terhadap tingkat stres pada mahasiswa psikologi angkatan 2012 yang sedang menyelesaikan skripsi di UIN Sunan Gunung Djati Bandung.

Berdasarkan data hasil penelitian dari jumlah subjek 49 menunjukkan bahwa sebanyak 6 subjek atau $12.24 \%$ berada dalam kategori self-disclosure tinggi, kemudian 35 subjek atau $71.43 \%$ berada dalam kategori sedang, dan 8 subjek atau $16.33 \%$ berada dalam kategori rendah. Sehingga dapat disimpulkan bahwa tingkatself-disclosure pada subjek penelitian berada dalam kategori sedang yaitu sebanyak 35 subjek atau $71.43 \%$.

Selanjutnya untuk variabel tingkat stres, dapat diketahui terdapat 6 subjek atau $12.24 \%$ berada dalam kategori tingkat stres tinggi, 34 subjek atau $69.39 \%$ berada dalam kategori sedang, dan 9 subjek atau $18.37 \%$ berada dalam kategori rendah. Sehingga dapat disimpulkan secara umum bahwa tingkat stres subjek penelitian sebagian besar berada dalam kategori sedang yaitu sebanyak 34 subjek atau $69.39 \%$.

Selanjutnya berdasarkan perhitungan data tabulasi silang, terdapat 3 subjek termasuk dalam kategori selfdisclosure tinggi dengan tingkat stres rendah dan 5 subjek berada dalam kategori self-disclosure rendah dengan tingkat stres sedang. Terdapat 5 subjek dalam kategori self-disclosure sedang dengan tingkat stres rendah, 25 subjek termasuk dalam kategori selfdisclosure sedang dengan tingkat stres sedang, dan 5 subjek termasuk kategori self-disclosure sedang dengan tingkat stres tinggi. Kemudian terdapat 1 subjek berada di kategori self- 
disclosure tinggi dengan tingkat stres rendah, 4 subjek pada kategori selfdisclosure tinggi dengan tingkat stres sedang, dan 1 subjek berada di kategori self-disclosure tinggi dengan tingkat stres tinggi.

Berdasarkan pengolahan data melalui analisis statistik diperoleh hasil bahwa yang diajukan diterima dan ditolak, yang berarti bahwa tidak terdapat pengaruh yang signifikan dari selfdisclosure terhadap tingkat stres pada subjek penelitian. Berdasarkan uji analisis regresi diperoleh koefisien korelasi dengan nilai $\mathrm{F}=.420$ dan signifikansi $.520>.05$, dengan koefisien determinasi sebesar .009 atau $.9 \%$ yang artinya pengaruh selfdisclosure terhadap tingkat stres sangat kecil dan tidak signifikan, hanya .9\% dan 99.1\%-nya dipengaruhi oleh faktor lain. Kemudian .648 <.679, artinya tidak terdapat pengaruh yang signifikan dari variabel satu terhadap variabel dua.

Hasil penelitian ini tidak sejalan dengan beberapa penelitian yang telah dilakukan sebelumnya yaitu penelitian Fauziyah (2011 dalam Suryaningsih, n.d) yang membuktikan bahwa selfdisclosure memiliki peran yang nyata dalam menurunkan stres pada remaja. Penelitian Santrock (2006) menjelaskan bahwa jika remaja memiliki masalah, maka mereka akan cenderung berpaling kepada teman sebaya mereka untuk mendapatkan jalan keluar dari masalah mereka. Hal tersebut dikarenakan pada masa remaja, teman memiliki peran yang cukup penting, selain itu masa remaja mempunyai kebutuhan sosial yang harus terpenuhi, salah satunya adalah peer group atau kelompok.

Hasil penelitian Wei, Russel, dan Zakalik (2005) menyatakan bahwa selfdisclosure terbukti dapat mengurangi rasa kesepian yang mengakibatkan stres dan depresi pada mahasiswa. Berdasarkan teori, salah satu tujuan self-disclosure menurut Derlega dan Grzelak (dalam Pamuncak,
2011) adalah self-clarification yaitu

dengan saling berbagi rasa serta menceritakan perasaan dan masalah yang sedang dihadapi kepada orang lain, seseorang berharap dapat memperoleh penjelasan dan pemahaman orang lain atas masalah yang dihadapinya, sehingga pikiran akan menjadi lebih jernih dan dapat melihat persoalannya dengan baik. Manfaat dari self-disclosure menurut DeVito (2011) salah satunya yaitu mengatasi kesulitan, dan akan lebih mampu menanggulangi masalah atau kesulitan.

Pada penelitian ini rata-rata usia subjek 22-25

tahun, berdasarkan tahapan perkembangan sudah memasuki usia dewasa awal. Dalam penelitian Parker dan Parot dijelaskan bahwa usia dewasa muda atau dewasa awal lebih sering mengungkapkan diri kepada teman daripada keluarga. Artinya pada masa ini pun, selfdisclosure masih mungkin dilakukan kepada teman-temannya, hampir sama dengan remaja.

Melihat hasil perhitungan yang sudah dibahas sebelumnya bahwa subjek memiliki self-disclosure sedang artinya mereka memiliki kemampuan untuk mengungkapkan diri, berbagi kepada orang lain mengenai masalah yang terkait dengan skripsinya kepada teman yang dianggap memahami masalahnya. Di sisi lain, tingkat stres yang dimiliki pun ternyata paling banyak berada pada tingkat sedang. Dari hal ini bisa dicermati meskipun tingkat selfdisclosure-nya paling banyak pada tingkat sedang tidak membuat tingkat stres-nya menurun. Kedua variabel berada di level yang sama, ini menunjukkan bahwa meskipun memiliki kemampuan untuk berbagi dan membuka diri, yang menurut Devito (2011) ketika seseorang bisa melakukan self-disclosure maka bisa menurunkan ketegangan atau stres, ternyata ini tidak berlaku bagi mahasiswa yang menjadi subjek penelitian ini. Kemampuan self-disclosure yang dimiliki tidak serta merta menurunkan tingkat stres 
karena tekanan dalam menyelesaikan skripsi. Tentunya ini sangat menarik untuk ditelaah lebih jauh.

Ada beberapa kemungkinan mengapa hasil penelitian ini menunjukkan tidak ada hubungan yang signifikan bahkan pengaruh variabel satu terhadap variabel duayang malah sangat kecil. Pertama, karena mahasiswa yang menjadi subjek penelitian adalah mahasiswa tingkat akhir dan sudah jarang sekali datang ke kampus kecuali untuk bimbingan dan mengurus penyelesaian penelitiannya. Diantara mahasiswa satu angkatanpun sudah jarang bertemu, sibuk masing-masing, mengingat jadwal bimbingan dan kepentingan penyelesaian penelitian bersifat individual, sehingga kesempatan untuk katarsis, berbagi cerita dengan teman juga sudah semakin sempit. Beberapa subjek yang peneliti amati, hanya mengungkapkan perasaan atau permasalahannya melalui media sosial saja. Berdasarkan hasil observasi daninterview yang dilakukan peneliti pada saat penelitan awal diperoleh informasi kalaupun mereka saling berbagi cerita, saling mengungkapkan kendala yang dialami, itu dilakukan tidak sengaja ketika mereka bertemu saat bimbingan dengan mahasiswa lain yang juga sedang bimbingan dengan dosen pembimbing yang berbeda. Mereka hanya bercerita sekedarnya tanpa ada unsur kedalaman atau ikatan antara satu dengan yang lain. Dari lima aspek selfdisclosure, nilai yang tinggi adalahamount (jumlah) yang menunjukkan mereka masih merasa sering bercerita tapi yang disampaikan hanya sebatas cerita saja tidak dibarengi dengan kedalaman atau penilaian (valensi) terhadap isi dari selfdisclosure. Self-disclosure yang dilakukan hanya sekedar cerita, karena tanpa sengaja bertemu, tanpa diniatkan untuk memahami dan menyelesaikan masalah. Sehingga aspek tujuan dan maksud yang menjadi salah satu aspek dalam tercapainya selfdisclosure tidak tercapai. Penting untuk memperhitungkan tujuan dan maksud dalam melakukan self-disclosure karena hal itu akan mengukur informasi yang harus ia bagi supaya tujuan dari selfdisclosure tercapai. Dari hal ini bisa disimpulkan, subjek hanya bercerita tanpa mementingkan aspek lain dari selfdisclosure seperti kejujuran, keakraban, tujuan dan maksudnya. Subjek hanya mengobrol untuk sekedar membuat perasaannya menjadi rileks tanpa ada nilai penting di dalamnya.

Kedua, secara teoretis terdapat banyak faktor yang berpengaruh signifikan terhadap tingkat stres, seperti tingkat selfesteem menurut (Zuntari, 2007 dalam Juniartha, n.d); (Farihah, 2014) selfefficacy berpengaruh terhadap stres pada mahasiswa. Dalam penelitiannya dikatakan bahwa pada hakekatnya stres adalah interaksi individu dengan lingkungan, menyebabkan adanya suatu tekanan dan memengaruhi aspek fisik, perilaku, kognitif, dan emosional. Tekanan yang dialami oleh individu bisa bersumber dari faktor internal, salah satu sumber stres dari faktor internal adalah keyakinan dan kemampuannya. Tingginya selfefficacy seseorang berkontribusi terhadap kemampuan seseorang menghadapi berbagai hambatan dan kesulitan yang dialami. Dengan keyakinan seseorang bahwa ia mampu untuk menyelesaikan sebuah tugas, maka seseorang tersebut akan mampu beradaptasi dengan kondisi sulit yang dialaminya sehingga tidak mudah tertekan dan semakin bisa menghadapi stres.

Selanjutnya, faktor lain yang dapat memengaruhi tingkat stres adalah regulasi emosi. Nurdin (2006) membuktikan bahwa mahasiswa dapat mengatasi stres dikarenakan mahasiswa tersebut mampu meregulasi emosinya sehingga stres yang muncul tidak menyebabkan mahasiswa itu terganggu; Kolat dkk. (n.d) (dalam Nurdin, 2006) yang menyatakan bahwa regulasi emosi merupakan strategi koping terhadap stres yang dialami mahasiswa ketika ada tekanan dalam penyelesaian tugas-tugas 
akademik. Wade dkk. (n.d) (dalam Nurdin, 2006) berpendapat bahwa mahasiswa yang mampu menilai situasi, mengubah pikiran yang negatif dan mengontrol emosinya akan memiliki koping yang positif terhadap masalahnya. Koping yang efektif membuat seseorang bisa adaptif dan meningkatkan kemampuan untuk bertahan dalam menghadapi kemungkinan stres selanjutnya. Regulasi emosi memainkan peran penting yang menumbuhkan kesadaran dalam memahami danmerespon stres dengan tepat. Berdasarkan penelitian tersebut bisa disimpulkan orang yang memiliki regulasi emosi yang baik akan mudah untuk menganggap biasa sumber-sumber stres di sekitarnya, tidak mudah untuk menganggap situasi sulit sebagai situasi yang menekan.

Ketiga, faktor lain yang membuat penelitian ini tidak memiliki hubungan yang signifikan adalah subjek pada penelitian ini termasuk usia dewasa awal, berdasarkan perkembangan emosi pada usia dewasa sudah lebih matang dibandingkan perkembangan emosi pada remaja, kemungkinan subjek pada penelitian ini lebih mature dalam menghadapi situasi stres sehingga curhat atau berbagi permasalahan kepada orang lain bukan merupakan suatu kebutuhan utama lagi, mereka sudah memiliki kemampuan lain yang bisa menurunkan tingkat stress karena masalah penyelesaikan skripsi. Beberapa peneliti amati meskipun stress tapi ia menyadari kalau itu adalah tugas yang harus ia selesaikan sampai tuntas.

Hal yang perlu diperhatikan lainnya adalah jumlah sample yang terbatas sehingga kurang mewakili permasalahan yang umumnya berkembang dilevel usia yang sama. Artinya hasil penelitian ini tidak bisa digeneralisir untuk semua level usia yang sama.

\section{Simpulan dan Saran}

\section{Simpulan}

Dari hasil penelitian yang dilakukan oleh peneliti dapat disimpulkan bahwa sebagian besar subjek yang diteliti memiliki tingkat self disclosure pada kategori sedang dan tingkat stres pada subjek sebagian besar berada pada kategori sedang.

Hasil analisis regresi menunjukan bahwa bahwa tidak terdapat pengaruh antara self disclosure terhadap tingkat stres. Berdasarkan hasil perhitungan, pengaruh aspek-aspek self disclosure terhadap tingkat stres menunjukan bahwa aspek amount (jumlah) atau seberapa sering melakukan self disclosure menunjukan angka yang paling mendekati signifikan dibandingkan aspek lainnya. Berarti kemungkinan subjek hanya membutuhkan untuk sering berbagi permasalahan yang dialaminya dan membutuhkan banyak teman untuk bercerita ketika mengalami situasi stres tanpa mempertimbangkan kedalaman, tujuan dan maksud maupun nilai dari self disclosure.

Faktor lain yang menyebabkan hipotesis dalam penelitian ini ditolak yaitu banyaknya aspek lain yang berpengaruh terhadap menurunnya tingkat stres seperti regulasi emosi, self efficacy, dan self esteem dan kemungkinan jumlah subjek yang tidak representatif.

\section{Saran}

Bagi subjek penelitian. Saran untuk mahasiswa yaitu harus memiliki keterampilan dalam berkomunikasi dan manfaatkan keterbukaan diri (self disclosure ) dengan baik dalam kehidupan sehari-hari agar mendapat wawasan dan informasi yang lebih luas mengenai diri sendiri atau lingkungan sekitar yang bisa dimanfaatkan untuk meurunkan stress.

Bagi instansi. Saran untuk instansi (Fakultas), diperlukan adanya sebuah pelatihan menulis karya ilmiah atau skripsi, agar mahasiswa lebih mudah dalam menyelesaikan tugas akhirnya.

Bagi penelitian selanjutnya. Lebih mematangkan konsep dan teori yang dipakai dalam penelitian. Peneliti dalam penelitian ini hanya bisa mengadaptasi alat 
ukur yang sudah ada. Agar lebih dapat menggali setiap aspeknya, hendaknya dikembangkan kembali. Untuk penelitian selanjutnya disarankan untuk dapat menambah variabel lain yang memiliki pengaruh lebih besar terhadap tingkat stres. Menambah subjek tidak hanya satu angkatan bahkan bisa dari fakultas lain yang dianggap memiliki beban kuliah yang sama.

\section{Daftar Pustaka}

Ables, J. L. (2013). Status, likes, and pokes: Self disclosure and motivation for using Facebook (Thesis). University of Baylor.

Abdulghani, H. M. (2008). Stress and depression among medical students: A cross sectional study at a medical college in Saudi Arabia. Pakistan Journal Medical Science, 24(1).

Rahman, A. A. (2013). Psikologi sosial. Jakarta: Rajagrafindo Persada.

Asandi, Q. R. (2010). Self disclosure pada remaja pengguna Facebook (Skripsi). UIN Sunan Ampel, Surabaya.

Devito, J. A. (2011). Komunikasi antar manusia (ed. 5). Tangerang Selatan: Karisma Publishing Group.

Fadillah, A. E. R. (2013). Stres dan motivasi belajar pada mahasiswa psikologi Universitas Mulawarman yang sedang menyusun skripsi. Ejournal Psikologi Universitas Mulawarman, 1(3).

Farihah, F. (2014). Pengaruh self efficacy terhadap stres mahasiswa angkatan 2010 yang menyusun skripsi fakultas psikologi UIN Maulana Malik Ibrahim Malang (Skripsi). UIN Maulana Malik Ibrahim, Malang.

Gainau, M. B. (2009). Keterbukaan diri (self disclosure) siswa dalam perspektif budaya dan implikasinya bagi konseling. Jurnal Penelitian Ilmiah Widya Warta, 3(1).

Goff, A. M. (2009). Stressors, academic, performance, and learned, resourfullness in baccalaureate nursing students (Disertasi). University of Carolina.

Gunawati, R. (2006). Hubungan antara efektivitas komunikasi mahasiswa dengan dosen pembimbing utama skripsi. Jurnal Psikologi Universitas Diponegoro, 3(2).

Juniartha, G. N. Hubungan antara harga diri dengan tingkat stres napi wanita di Lapas Kelas II Denpasar. Jurnal. Universitas Udayana.

Rini, Kartika, \& Qurroyzhin. (2007). Hubungan antara keterbukaan diri dengan kebahagiaan pernikahan pada pria dewasa awal (Skripsi). Gunadarma University.

Larasaty, R. (2012). Hubungan tingkat stres dengan sleep paralysis pada mahasiswa FIK UI angkatan 2008 (Skripsi). Fakultas Keperawatan, Universitas Indonesia.

Lazarus, R. S., \& Folkman, S. (1984). Stress, appraisal, and coping. New York: Springer Publishing Company.

Nurdin, Z. (2016). Hubungan regulasi emosi dengan tingkat stres pada mahasiswa tingkat akhir pendidikan dokter fakultas kedokteran Universitas Syiah Kuala Banda Aceh (Skripsi). Universitas Syiah Kuala, Banda Aceh.

Pamuncak, D. (2011). Pengaruh tipe kepribadian terhadap self disclosure pengguna Facebook (Skripsi). UIN Syarif Hidayatullah, Jakarta.

Parker, G. R., \& Parrot, R. (1995). Patterns of self disclosure across social support networks: Elderly, middle-aged, and young adults. The International Journal of Aging and Human Development, 41, 281-297.

Rime, B. (2016). Self disclosure. Dalam H. S. Friedman (Ed.), Encyclopedia of Mental Health (ed. 2, vol. 4) (pp. 6674). Waltham, MA: Academic Press.

Rini, K., \& Qurroyzhin. (2007). Hubungan antara keterbukaan diri dengan kebahagiaan pernikahan pada pria 
dewasa awal (Skripsi). Gunadarma University.

Safaria, T., \& Saputra, N. E. (2009). Managemen emosi. Jakarta: PT Bumi Aksara.

Santrock, J. W. (2006). Adolescence perkembangan remaja. Jakarta: Penerbit Erlangga.

Sarafino, E. P. (1994). Health psychology: Biopsychososial interactions.

Septiani, E. (2013). Hubungan antara tingkat stres dengan gaya humor pada mahasiswa (Skripsi). UIN SGD Bandung.

Sugiyono. (2012). Metode penelitian kuantitatif kualitatif dan $R$ \& $D$. Bandung: Alfabeta.

Suryaningsih. Hubungan self disclosure dengan stres pada remaja siswa SMP Negeri 8 Surakarta. Jurnal. Universitas Sebelas Maret.

Wei, M., Russel, D. W., \& Zakalik, R. A. (2005). Adult attachment, social self efficccy, self disclosure, loneliness, and subsequent depression for freshman colege student: A longnitudinal study. Journal of Counseling Psychology, 52(4).

Wheeless, L. R., Nesser, K., \& Mccroskey, J. C. (1986). The relationships of selfdisclosure and disclosiveness to high and low communication apprehension, communication research reports. (Online) Diakses dari http://www.jamescmccroskey.com/pub lications/137.pdf

Wulandari, R. P. (2012). Hubungan tingkat stres dengan gangguan tidur pada mahasiswa skripsi di salah satu fakultas rumpun science-technology UI (Skripsi). Universitas Indonesia, Depok.

Zhang, R. (2017). The stress buffering effect of self disclosure on Facebook: An examination of stressfull life events, social support, and mental health among college students. Journal Computer in Humans Behaviour, 75, 527-537. 
Psympathic, Jurnal Ilmiah Psikologi Juni 2018, Vol. 5, No. 1, Hal: 115-130 